\title{
Predictors of a complicated course after surgical repair of tetralogy of Fallot
}

\author{
Fallot tetralojisinin cerrahi onarımı sonrasında komplike seyrin öngördürücüleri

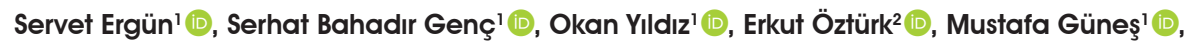

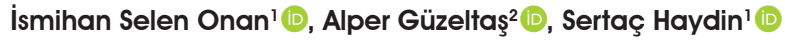

\begin{abstract}
'Department of Pediatric Cardiovascular Surgery, Mehmet Akif Ersoy Thoracic and Cardiovascular Training and Research Hospital, Istanbul, Turkey 2Department of Pediatric Cardiology, Mehmet Akif Ersoy Thoracic and Cardiovascular Training and Research Hospital, Istanbul, Turkey
\end{abstract}

\begin{abstract}
Background: In this study, we aimed to evaluate the patient and surgical factors affecting prolonged hospital stay and major adverse events after surgical repair of tetralogy of Fallot and to identify the predictors of a complicated course after surgical repair.

Methods: A total of 170 consecutive patients (96 males, 74 females; median age 12 months; range, 1 to 192 months) who underwent surgical repair of tetralogy of Fallot between January 2015 and April 2018 were retrospectively reviewed. A mechanical ventilation duration of $>24 \mathrm{~h}$, an intensive care unit stay of $>3$ days, and a hospital stay of $>7$ days were considered as prolonged. Unplanned reoperation, complete heart block requiring a permanent pacemaker implantation, renal failure, diaphragmatic paralysis, neurological deficit, sudden circulatory arrest, need for extracorporeal membrane oxygenation, and death were considered as major adverse events.
\end{abstract}

Results: The median time to hospital discharge was 8.0 (range, 5.0 to 40.0) days. Higher preoperative hematocrit levels prolonged the length of hospital stay (odds ratio: 1.12, 95\% confidence interval 1.1-1.2, $\mathrm{p}<0.001$ ). A total of 28 major adverse events were observed in 17 patients $(10 \%)$. Lower pulmonary artery annulus Z-score (odds ratio: $0.5,95 \%$ confidence interval $0.3-0.9$, $\mathrm{p}=0.01$ ) and residual ventricular septal defects (odds ratio: $54.6,95 \%$ confidence interval $1.6-1,874.2, \mathrm{p}=0.03$ ) were found to increase mortality. Residual ventricular septal defect was also a risk factor for major adverse events (odds ratio: 12.4, 95\% confidence interval $1.5-99.9, \mathrm{p}=0.02)$.

Conclusion: Preoperative and operative factors such as high preoperative hematocrit, low preoperative oxygen saturation, low pulmonary annulus Z-score, Down syndrome, residual ventricular septal defects, and the use transannular patch were found to be associated with prolonged length of hospital stay, prolonged mechanical ventilation, prolonged intensive care unit stay, and increased development of major adverse events.

Keywords: Length of hospital stay, major adverse event, morbidity, mortality, tetralogy of Fallot.

\section{$\ddot{O} Z$}

Amaç: Bu çalışmada Fallot tetralojisinin cerrahi onarımından sonra hastanede uzayan kalış süresini ve majör advers olayları etkileyen hasta ve cerrahi faktörler değerlendirildi ve cerrahi onarım sonrasında komplike seyrin öngördürücüleri belirlendi.

Çalışma planı: Ocak 2015-Nisan 2018 tarihleri arasında Fallot tetralojisinin cerrahi onarımı yapılan toplam 170 ardışı hasta (96 erkek, 74 kız; medyan yaş 12 ay; dağılım, 1-192 ay) retrospektif olarak incelendi. Yirmi dört saatten fazla mekanik ventilasyon süresi, >3 günlük yoğun bakım ünitesinde kalış ve $>7$ günlük hastanede kalış süresi uzamış olarak kabul edildi. Planlanmamış tekrar ameliyat, kalıcı kalp pili takılmasını gerektiren tam kalp bloku, böbrek yetmezliği, diyafram paralizisi, nörolojik defisit, ani dolaşım arresti, ekstrakorporeal membran oksijenasyon gereksinimi ve ölüm majör advers olaylar olarak kabul edildi.

Bulgular: Medyan hastaneden taburculuk süresi 8.0 (dağılım, 5.0-40.0) gün idi. Ameliyat öncesi yüksek hematokrit düzeyleri, hastanede kalış süresini uzattı (olasılık oranı: 1.12, \%95 güven aralığ1 1.1-1.2, p<0.001). On yedi hastada (\%10) toplam 28 majör advers olay gözlendi. Alt pulmoner arter anülüs $\mathrm{Z}$ skoru (olasılık oranı: 0.5 , \%95 güven aralığg $0.3-09, \mathrm{p}=0.01)$ ve rezidüel ventriküler septal defektlerin (olasılık oranı: 54.6, \%95 güven aralı $\left.\breve{g}_{1} 1.6-1874.2, \quad \mathrm{p}=0.03\right)$ mortaliteyi artırdı $\breve{g}_{1}$ tespit edildi. Rezidüel ventriküler septal defekt de, majör advers olay açısından bir risk faktörü idi (olasılık oranı: 12.4, \%95 güven aralığı 1.5-99.9, $\mathrm{p}=0.02$ ).

Sonuç: Ameliyat öncesi yüksek hematokrit, ameliyat öncesi düşük oksijen satürasyonu, alt pulmonar anulüs $\mathrm{Z}$ skoru, Down sendromu, rezidüel ventriküler septal defektler ve transannüler yama kullanımı gibi ameliyat öncesi ve ameliyat sırası faktörler, hastanede kalış süresinde uzama, mekanik ventilasyonda uzama, yoğun bakım ünitesinde kalış süresinde uzama ve majör advers olay gelişiminde artış ile ilişkili bulundu.

Anahtar sözcükler: Hastanede kalış süresi, majör advers olay, morbidite, mortalite, Fallot tetralojisi. Kliniği, 34303 Küçükçekmece, İstanbul, Türkiye. Tel: +90 532 - 5817412 e-mail: drservetergun41@gmail.com 
Over the last decades, surgical treatment and postoperative care for tetralogy of Fallot (TOF) has improved tremendously. Although the age at surgical repair of TOF has been reduced, the mortality rate is $<2 \%$ in developed countries and $3.6 \%$ in developing countries. $^{[1,2]}$ However, there are still risks of a complicated course from heart block, reoperation due to residual defects, and prolonged hospital stays. ${ }^{[3]}$ The length of hospital stay (LOHS) is an important surgical outcome and is associated with long-term results, such as the neurodevelopmental outcomes. ${ }^{[4,5]}$ There are also reports that prolonged hospital stay is associated with long-term adverse events. ${ }^{[6,7]}$ Scant data are available related to the LOHS and major adverse events (MAEs) in patients undergoing surgical repair in developing countries. The age of complete repair of TOF has gradually decreased in Turkey as in other countries. However, our patient population has recently changed due to Syrian refugees, and the age of the operation has increased. Currently, Turkey has been hosting over 3.6 million registered Syrian refugees and the majority of them are under the age of 18. Although most centers want early repair during the first year of life, the diagnosis can be delayed, and some patients become worsen with severe cyanosis due to poor socioeconomic conditions.

In the present study, we aimed to evaluate the patient and surgical factors affecting prolonged hospital stay and MAEs after surgical repair of TOF and to identify the predictors of a complicated course after surgical repair of TOF.

\section{PATIENTS AND METHODS}

In this single-center study, we retrospectively reviewed a total of 170 consecutive patients (96 males, 74 females; median age 12 months; range, 1 to 192 months) who underwent surgical TOF repair between January 2015 and April 2018. Only patients who previously had palliation (surgery or catheter) were included in the study. Those diagnosed with TOF with absent pulmonary valve and TOF with pulmonary atresia with major aortopulmonary collateral artery (MAPCA) were excluded. A written informed consent was obtained from each parent. The study protocol was approved by the Mehmet Akif Ersoy Thoracic and Cardiovascular Training and Research Hospital Ethics Committee. The study was conducted in accordance with the principles of the Declaration of Helsinki.

Preoperative demographic and clinical data, previous history, surgical data, perfusion data, clinical follow-up, and pre- and postoperative echocardiography reports were evaluated for each patient retrospectively. Extracardiac findings and genetic syndromes were recorded. Pulmonary annulus, main pulmonary artery (MPA), and right pulmonary artery (RPA) and left pulmonary artery (LPA) Z-scores were noted by preoperative review of reports from imaging modalities such as computed tomography or magnetic resonance imaging or procedures such as catheterizations.

Our primary outcome measure was to determine the parameters affecting prolonged hospital stay after TOF surgical repair. Our secondary measure to investigate the factors leading to the development of MAE and the mortality rate after TOF surgical repair. The risk factors for prolonged mechanical ventilation (MV) and intensive care unit (ICU) were evaluated.

Major adverse events included complete atrioventricular (AV) block requiring pacemaker implantation, renal failure, diaphragmatic paralysis, neurological deficit, unplanned reoperation due to residual lesions, sudden circulatory arrest, need for postoperative mechanical circulation support, or death. ${ }^{[3]}$ Complications except for MAEs were defined as pulmonary complications (i.e., atelectasis, pneumothorax, hemothorax, or pleural effusion), re-intubation, arrhythmia (junctional ectopic tachycardia [JET], temporary complete AV block, infection (except for superficial wound infection), wound infections, development of restrictive physiology, delayed sternal closure, post-pericardiotomy syndrome, chylothorax, and rehospitalization (within 30 days postoperatively). Restrictive physiology diagnosis was made in the early postoperative period after the detection of end-diastolic forward flow on echocardiographs in patients with low cardiac output and a need for inotropic drugs.

The LOHS was defined as the time between the day of operation and the day of discharge. A MV duration of $>24 \mathrm{~h}$, ICU duration of $>3$ days, and hospital stay of $>7$ days were considered as prolonged..$^{[1-3,8-11]}$ The patients were divided into two groups according to the LOHS (shorter and longer than seven days) and age (under one year and older).

\section{Surgical technique}

In our clinic, we do not perform complete correction operation in the neonatal period. In this period, we prefer palliation with catheterization (right ventricular outflow tract [RVOT] stenting, patent ductus arteriosus [PDA] stenting, pulmonary artery balloon valvuloplasty) if possible or, otherwise, with a shunt. We perform complete correction operation for patients three to 12 months old. ${ }^{[7]}$ We apply a patientbased approach in patients one to three months old. 
Under standard median sternotomy and cardiopulmonary bypass (CPB), ventricular septal defects (VSDs) were closed with a pericardial patch or bovine pericardium using the continuous suture technique. For RVOT repair, the followings were used: (i) muscle band resection with the transatrial and transpulmonary approach; (ii) infundibulotomy without a transannular patch (TAP); (iii) TAP; (iv) TAP

Table 1. Baseline characteristics of all patients $(n=170)$

\begin{tabular}{|c|c|c|c|c|}
\hline Variables & $\mathrm{n}$ & $\%$ & Median & Min-Max \\
\hline Age (month) & & & 12 & $1-192$ \\
\hline Weight $(\mathrm{kg})$ & & & 8.4 & $3.3-65.0$ \\
\hline Body surface area $\left(\mathrm{m}^{2}\right)$ & & & 0.4 & $0.2-1.8$ \\
\hline \multicolumn{5}{|l|}{ Gender } \\
\hline Male & 96 & 56.8 & & \\
\hline \multicolumn{5}{|l|}{ Diagnosis } \\
\hline TOF & 165 & 97.1 & & \\
\hline TOF and AVSD & 5 & 2.9 & & \\
\hline \multicolumn{5}{|l|}{ Additional pathologies } \\
\hline Additional muscular VSD & 4 & 2.4 & & \\
\hline Doubly committed VSD & 1 & 0.6 & & \\
\hline LPA disconnection & 5 & 2.9 & & \\
\hline RPA disconnection & 1 & 0.6 & & \\
\hline LPA proximal stenosis & 10 & 5.9 & & \\
\hline RPA proximal stenosis & 6 & 3.5 & & \\
\hline MPA hypoplasia & 5 & 2.9 & & \\
\hline LPA hypoplasia & 9 & 5.3 & & \\
\hline LPA and RPA hypoplasia & 1 & 0.6 & & \\
\hline PA bifurcation stenosis & 8 & 4.7 & & \\
\hline Coronary anomaly & 6 & 3.5 & & \\
\hline Biventricular noncompaction & 1 & 0.6 & & \\
\hline Right arcus aorta and aberrant & 2 & 1.2 & & \\
\hline \multicolumn{5}{|l|}{ LSCA } \\
\hline Tricuspid valve vegetation & 1 & 0.6 & & \\
\hline Thrombosis at the site of distal arcus aorta & 1 & 0.6 & & \\
\hline Noncardiac anomalies & 29 & 17.1 & & \\
\hline Down syndrome & 13 & 7.7 & & \\
\hline DiGeorge syndrome & 6 & 3.5 & & \\
\hline Others & 10 & 5.9 & & \\
\hline \multicolumn{5}{|l|}{ Palliation } \\
\hline PDA stent & 26 & 15.3 & & \\
\hline RVOT stent & 3 & 1.8 & & \\
\hline Pulmonary artery balloon valvuloplasty & 5 & 2.9 & & \\
\hline Shunt & 9 & 5.3 & & \\
\hline Pulmonary annulus Z-score & & & -1.3 & $-7.3-+3$ \\
\hline MPA Z-score & & & -2.5 & $-7.6-+2.6$ \\
\hline RPA Z-score & & & 1.7 & $-3.8-+4.9$ \\
\hline LPA Z-score & & & 1.9 & $-6.8-+4.9$ \\
\hline McGoon index & & & 2.2 & $0.8-4.2$ \\
\hline The Aristotle Basic Complexity Score (ABC score) & & & 8.0 & $6.3-11$ \\
\hline The Aristotle Comprehensive Complexity Score (ACC Score) & & & 8.5 & $6.3-18$ \\
\hline Preoperative hematocrit $(\%)$ & & & 42.7 & $25.1-65.4$ \\
\hline Preoperative oxygen saturation $(\%)$ & & & 90.0 & $20.0-100.0$ \\
\hline
\end{tabular}

Min: Minimum; Max: Maximum; TOF: Tetralogy of Fallot; AVSD: Atrioventricular septal defect; VSD: Ventricular septal defect; LPA: Left pulmonary artery; RPA: Right pulmonary artery; MPA: Mean pulmonary artery; PA: Pulmonary atresia; LSCA: Left subclavian artery; PDA: Patent ductus arteriosus; RVOT: Right ventricle outflow tract. 
with pulmonary valve anterior leaflet augmentation (ALA); and (v) right ventricular-pulmonary artery (RV-PA) conduit. When needed, patch plasty was applied to the RPA and LPA.

The Qp/Qs ratio was evaluated in the presence of residual VSD. If the Qp/Qs ratio was $>1.3$, VSD was considered to be hemodynamically significant and residual VSD was closed by entering $\mathrm{CPB}$ again.

First, supravalvular and subvalvular stenoses were completely removed and the pulmonary valve was evaluated. Leaflet thinning, delamination, and commissurotomy were performed, if necessary. The valve was preserved, when the Hegar bougie one size less than appropriate size could be passed. Otherwise, TAP and ALA were performed in the appropriate patient group. In cases where right ventricular/left ventricular $(\mathrm{RV} / \mathrm{LV})$ pressure ratio was above $0.7, \mathrm{CPB}$ was reinstituted and residual RVOT obstruction was relieved. We did not hesitate to apply TAP, if a pressure ratio above 0.7 was detected in our clinic.

Additional pathologies (atrial septal defects [ASDs], PDA, and tricuspid valve repair, if necessary) were managed appropriately. Apart from outpatient echocardiography, all patients were evaluated perioperatively with transthoracic and transesophageal echocardiography, if needed. The patients were also evaluated with transthoracic echocardiography on postoperative Day 1 in the ICU and before discharge.

\section{Statistical analysis}

Statistical analysis was performed using the IBM SPSS version 22.0 software (IBM Corp., Armonk, NY, USA). The normal distribution of variables was evaluated visually (histogram and probability graphs) and analytically (Kolmogorov-Smirnov and ShapiroWilk tests). Descriptive data were expressed in mean \pm standard deviation (SD), median (min-max) or number and frequency. For the group comparison, independent samples t-test was used for parametric (continuous) variables, whereas the Mann-Whitney $U$ test was used for non-parametric variables. For the analysis of predictive risk factors for outcome variables, univariate analysis was used. Variables with a $p$ value of $<0.10$ in the univariate analysis and that were non-correlated with each other were included in the multivariate logistic regression analysis. A $p$ value of $<0.05$ was considered statistically significant.

Table 2. Operative data

\begin{tabular}{|c|c|c|c|c|}
\hline Variables & $\mathrm{n}$ & $\%$ & Median & Min-Max \\
\hline The need for branch pulmonary artery plasty & 39 & 22.9 & & \\
\hline Coronary artery anomaly at the operation & 6 & 3.5 & & \\
\hline \multicolumn{5}{|l|}{ Outflow tract repair } \\
\hline Ventriculotomy and transannular patch plasty & 115 & 67.6 & & \\
\hline ALA and transannular patch plasty & 35 & 20.6 & & \\
\hline Ventriculotomy and no transannular patch plasty & 41 & 24.1 & & \\
\hline Transatrial and transpulmonary approach & 10 & 5.9 & & \\
\hline Pulmonary conduit replacement & 4 & 2.4 & & \\
\hline Hypothermia $\left({ }^{\circ} \mathrm{C}\right)$ & & & 33.0 & $26.0-36.0$ \\
\hline CPB time (min) & & & 144.0 & $57.0-317.0$ \\
\hline Reinstitution of CPB & 9 & 5.3 & & \\
\hline Cross clamp time (min) & & & 104.0 & $49.0-216.0$ \\
\hline $\mathrm{RV} / \mathrm{LV}$ pressure ratio at the end of operation & & & 0.5 & $0.2-0.7$ \\
\hline \multicolumn{5}{|l|}{ The degree of PVI at the end of operation } \\
\hline Trivial & 17 & 10 & & \\
\hline Mild & 6 & 3.6 & & \\
\hline Moderate & 63 & 37 & & \\
\hline Severe & 80 & 47 & & \\
\hline Residual VSD at the end of operation & 10 & 5.9 & & \\
\hline$<2 \mathrm{~mm}$ & 6 & 3.5 & & \\
\hline $2-4 \mathrm{~mm}$ & 4 & 2.4 & & \\
\hline RV-PA gradient at the end of operation $(\mathrm{mmHg})$ & & & 20.0 & $0-35.0$ \\
\hline
\end{tabular}

Min: Minimum; Max: Maximum; ALA: Anterior leaflet augmentation; CPB: Cardiopulmonary bypass; RV: Right ventricle; LV: Left ventricle; PVI: Pulmonary valve insufficiency; VSD: Ventricular septal defect; PA: pulmonary artery. 
Table 3. Non-major adverse events

\begin{tabular}{lcccc}
\hline Variables & $\mathrm{n}$ & $\%$ & Median & Min-Max \\
\hline Delayed sternal closure & 8 & 4.7 & & \\
Junctional ectopic tachycardia & 13 & 7.6 & & \\
Transient AV block & 5 & 2.9 & & \\
Infection & 12 & 7.1 & & \\
Pulmonary complication & 43 & 25.3 & & \\
$\quad$ Wound infection & 4 & 2.4 & & \\
$\quad$ Reintubation & 25 & 14.7 & & \\
$\quad$ Restrictive physiology & 31 & 18.2 & & $0.3-4.6$ \\
$\quad$ Follow-up (year) & & & 1.8 & $2.0-720.0$ \\
$\quad$ Ventilation time (h) & & & 16.0 & $1.0-36.0$ \\
$\quad$ Prolonged ventilation time (>24 h) & 41 & 24.1 & & \\
$\quad$ ICU LOS (day) & & & 3.0 & \\
$\quad$ Prolonged ICU LOS (>3 days) & 80 & 47.1 & & \\
$\quad$ Hospital LOS (day) & & & 8.0 & $1.0-40.0$ \\
$\quad$ Prolonged hospital LOS (>7 days) & 105 & 61.7 & & \\
\hline
\end{tabular}

Min: Minimum; Max: Maximum; AV: Atrioventricular; ICU: Intensive care unit; LOS: Length of hospital stay.

\section{RESULTS}

Table 1 shows the demographic data of the study population. Of the patients, $106(62.3 \%)$ were over one year old. The median weight was 8.4 (range, 3.3 to 65.0$) \mathrm{kg}$. One hundred sixty-five patients $(97.1 \%)$ had the diagnosis of TOF, while five $(2.9 \%)$ had the diagnosis of TOF and atrioventricular septal defect (AVSD). A total of 144 patients $(84.7 \%)$ underwent primary repair. The remaining 26 patients (15.3\%) previously underwent palliative procedures. Of these, nine $(5.3 \%)$ had a modified Blalock-Taussig (BT) shunt, nine $(5.3 \%)$ had pulmonary balloon valvuloplasty, five $(2.9 \%)$ had a RVOT stent, and three (1.8\%) had a PDA stent. Twenty-nine patients (17.1\%) had genetic syndromes. Of these, 13 (7.6\%) had Down syndrome, and six $(3.5 \%)$ had DiGeorge syndrome. Thirty-nine (22.9\%) of the patients were refugees. The mean age of these patients was higher ( 12 vs. 21.2 months; $p=0.04$ ) and the mean hematocrit level of these patient was higher ( $42.7 \%$ vs. $48.6 \%$; $\mathrm{p}=0.05)$.

The median $\mathrm{Z}$-score of pulmonary annulus was -1.3 (range, -7.3 to +3 ) and the mean pulmonary artery (PA) Z-score was $-2.4 \pm 2.3$. The median preoperative hematocrit level was $42.7 \%$ (range, 25.1 to 65.4 ) and the median preoperative oxygen saturation $\left(\mathrm{SaO}_{2}\right)$ was 90.0 (range, 20.0 to 100.0).

Transannular patch was performed in 115 patients $(67.6 \%)$, and in $35(20.6 \%)$ of these patients, TAP plus ALA was performed. A total of 41 patients $(24.1 \%)$ underwent ventriculotomy plus non-TAP, 10 patients $(5.9 \%)$ underwent the transpulmonary plus transatrial approach, and four patients $(2.4 \%)$ had a conduit. The median postoperative RV/LV pressure ratio was 0.5 (range, 0.2 to 0.7 ). The median RV-PA pressure gradient was $20.0 \mathrm{mmHg}$ (range, 0 to 35), while 39 patients $(22.9 \%)$ received patch plasty of the RPA or LPA. In nine patients (5.3\%), CPB was reinstituted and RVOT intervention was performed. Ten patients (5.9\%) had residual VSD. The residual VSD diameter was $2 \mathrm{~mm}$ or $<2 \mathrm{~mm}$ in six patients $(3.5 \%)$. Four patients $(2.4 \%)$ had residual VSDs of 2 to $4 \mathrm{~mm}$. There was trivial pulmonary insufficiency (PI) in 17 patients (10\%). Six (3.5\%) had mild PI, 63 (37.1\%) had moderate PI, and $80(47 \%)$ had severe PI (Table 2). The patients with severe PI were those with a TAP and without ALA.

The most common complication was pulmonary in 43 patients (25.3\%). Junctional ectopic tachycardia

Table 4. Major adverse events $(n=170)$

\begin{tabular}{lcc}
\hline Variables & $\mathrm{n}$ & $\%$ \\
\hline Permanent atrioventricular block & 5 & 2.9 \\
Neurological complication & 3 & 1.8 \\
Renal disfunction & 1 & 0.6 \\
Reoperation for a significant residual lesion & 4 & 2.4 \\
Cardiopulmonary resuscitation & 2 & 1.2 \\
Extracorporeal membrane oxygenation & 7 & 4.1 \\
Early mortality & 6 & 3.5 \\
Major adverse event* & 17 & 10 \\
\hline
\end{tabular}

* A total of 28 major adverse events developed in 17 (10\%) patients. 
Table 5. Independent risk factors for hospital stay, ICU stay and MV duration in multivariate analysis

\begin{tabular}{|c|c|c|c|c|}
\hline Variables & OR & $95 \%$ CI lower & 95\% CI upper & $p$ \\
\hline \multicolumn{5}{|l|}{ Length of hospital stay } \\
\hline Preoperative hematocrit & 1.12 & 1.1 & 1.2 & $<0.001$ \\
\hline \multicolumn{5}{|l|}{ ICU stay } \\
\hline Preoperative $\mathrm{SaO}_{2}$ & 0.9 & 0.9 & 1.0 & 0.02 \\
\hline Ventriculotomy and transannular patch plasty & 1.01 & 1.0 & 1.03 & 0.04 \\
\hline \multicolumn{5}{|l|}{ MV duration } \\
\hline Age & 0.85 & 0.7 & 0.9 & 0.03 \\
\hline RPA Z-score & 0.76 & 0.6 & 1.0 & 0.05 \\
\hline Down syndrome & 16.4 & 2.7 & 99.2 & 0.002 \\
\hline Ventriculotomy and transannular patch plasty & 2.13 & 1.05 & 4.31 & 0.04 \\
\hline
\end{tabular}

ICU: Intensive care unit; MV: Mechanical ventilation; OR: Odds ratio; CI: Confidence interval; $\mathrm{SaO}_{2}$ : Oxygen saturation; RPA: Right pulmonary artery.

was observed in 13 patients $(7.6 \%)$ and transient $\mathrm{AV}$ block was observed in five patients $(2.9 \%)$. Infection (i.e., sepsis, urinary tract infection) was observed in 12 patients (7.1\%). Restrictive physiology was seen in 31 patients $(18.2 \%)$ (Table 3$)$.

A total of 28 MAEs were observed in 17 patients $(10 \%)$. Renal dysfunction in one $(0.6 \%)$, complete $\mathrm{AV}$ block requiring pacemaker implantation in five (2.9\%), neurological deficit in three $(1.8 \%)$, extracorporeal membrane oxygenation (ECMO) requirement in seven $(4.1 \%)$, and cardiopulmonary resuscitation was performed in two patients (1.2\%). In-hospital mortality was six $(3.5 \%)$ (Table 4$)$.

The mean LOHS was eight (range, 1 to 40) days. Multivariate analysis showed that younger age, low PA Z-scores, patients with Down syndrome, and TAP prolonged the MV duration. High preoperative hematocrit values were found to prolong the duration of LHOS (odds ratio: 1.12; 95\% CI: 1.1-1.2; $\mathrm{p}=0.001$ ). The use of TAP (odds ratio: 1.01; 95\% CI: $1.0-1.03 ; \mathrm{p}=0.04$ )

Table 6. Postoperative results according to length of hospital stay

\begin{tabular}{|c|c|c|c|c|c|c|c|c|c|}
\hline \multirow[b]{2}{*}{ Variables } & \multicolumn{4}{|c|}{$\begin{array}{l}\text { Hospital stay } \leq 7 \text { days } \\
(\mathrm{n}=65)\end{array}$} & \multicolumn{4}{|c|}{$\begin{array}{l}\text { Hospital stay }>7 \text { days } \\
\qquad(\mathrm{n}=105)\end{array}$} & \multirow[b]{2}{*}{$p$} \\
\hline & $\mathrm{n}$ & $\%$ & Median & Min-Max & $\mathrm{n}$ & $\%$ & Median & Min-Max & \\
\hline Complications & 11 & 17.2 & & & 70 & 67.3 & & & $<0.001 *$ \\
\hline Major adverse event & 3 & 4.7 & & & 16 & 15.2 & & & $0.04 *$ \\
\hline Early mortality & 1 & 1.6 & & & 5 & 4.8 & & & 0.28 \\
\hline Reintubation & 1 & 1.6 & & & 24 & 22.9 & & & $<0.001^{*}$ \\
\hline Infection & 1 & 1.6 & & & 11 & 10.5 & & & $0.03 *$ \\
\hline Wound infection & 0 & 0 & & & 4 & 3.8 & & & 0.11 \\
\hline Restrictive physiology & 2 & 3.1 & & & 29 & 27.6 & & & $<0.001 *$ \\
\hline Arrhythmia & 6 & 3.5 & & & 47 & 27.6 & & & $0.01 *$ \\
\hline Delayed sternal closure & 0 & 0 & & & 8 & 7.6 & & & $0.02^{*}$ \\
\hline Ventilation time (h) & & & 12 & $8-16$ & & & 18 & $12-52$ & $<0.001 *$ \\
\hline Prolonged ventilation time $(>24 \mathrm{~h})$ & 3 & 4.7 & & & 38 & 36.2 & & & $<0.001^{*}$ \\
\hline ICU LOS (day) & & & 2 & $2-3$ & & & 5 & $3-8$ & $<0.001^{*}$ \\
\hline Prolonged ICU LOS (> 3 days) & 12 & 18.8 & & & 68 & 64.8 & & & $<0.001 *$ \\
\hline Hospital LOS (day) & & & 7 & $6-7$ & & & 12 & $9-18$ & $<0.001 *$ \\
\hline
\end{tabular}

Min: Minimum; Max: Maximum; ICU: Intensive care unit; LOS: Length of hospital stay 
Table 7. Independent risk factors for mortality, major adverse event, and hospital stay in multivariate analysis

\begin{tabular}{|c|c|c|c|c|}
\hline Variables & OR & $95 \%$ CI lower & $95 \%$ CI upper & $p$ \\
\hline \multicolumn{5}{|l|}{ Mortality } \\
\hline Annulus Z-score & 0.5 & 0.3 & 0.9 & 0.01 \\
\hline Residual VSD 2-4 mm & 54.6 & 1.6 & $1,874.2$ & 0.03 \\
\hline \multicolumn{5}{|l|}{ Major adverse event } \\
\hline Residual VSD 2-4 mm & 12.4 & 1.5 & 99.9 & 0.02 \\
\hline \multicolumn{5}{|l|}{ Hospital stay } \\
\hline Preoperative hematocrit & 1.12 & 1.1 & 1.2 & $<0.001$ \\
\hline
\end{tabular}

OR: Odds ratio; CI: Confidence interval; VSD: Ventricular septal defect.

and low preoperative saturation (odds ratio: $0.9 ; 95 \%$ CI: $0.9-1.0 ; \mathrm{p}=0.02$ ) had an effect on prolonged ICU stay (Table 5).

The patients were divided into two groups according to the LOHS as shorter and longer than seven days. The duration of hospitalization was longer than seven days for 105 patients $(61.7 \%)$. Major adverse events $(\mathrm{p}=0.04)$ and non-MAE complications $(\mathrm{p}<0.001)$ were more frequent in patients hospitalized longer than seven days. However, no statistically significant difference was observed between the groups in terms of early mortality $(p=0.28)$. There was a statistically significant difference between the groups in terms of delayed sternal closure $(\mathrm{p}<0.001)$, prolonged ventilation time $(\mathrm{p}<0.001)$, and prolonged ICU stay $(\mathrm{p}<0.001)$. A statistically significant difference was also observed between the groups in terms of arrhythmia $(\mathrm{p}=0.01)$, restrictive physiology $(\mathrm{p}<0.001)$, infection $(\mathrm{p}=0.03)$, and reintubation $(\mathrm{p}<0.001)$ (Table 6).

Lower PA annulus Z-score (odds ratio: $0.5 ; 95 \% \mathrm{CI}$ : $0.3-0.9 ; \mathrm{p}=0.01$ ) and residual VSD (odds ratio: 54.6; 95\% CI: $1.6-1,874.2 ; \mathrm{p}=0.03$ ) were found to increase mortality. Residual VSD was also a risk factor for a MAE (odds ratio: $12.4 ; 95 \%$ CI: $1.5-99.9 ; \mathrm{p}=0.02$ ) (Table 7).

A total of $106(62.3 \%)$ of the patients were over one year old. Infection development, delayed sternal

Table 8. Postoperative results according to age groups

\begin{tabular}{|c|c|c|c|c|c|c|c|c|c|}
\hline \multirow[b]{2}{*}{ Variables } & \multicolumn{4}{|c|}{ Age $<1 \quad(n=63)$} & \multicolumn{4}{|c|}{ Age $\geq 1 \quad(n=106)$} & \multirow[b]{2}{*}{$p$} \\
\hline & $\mathrm{n}$ & $\%$ & Median & Min-Max & $\mathrm{n}$ & $\%$ & Median & Min-Max & \\
\hline Complications & 33 & 52.4 & & & 48 & 45.7 & & & 0.40 \\
\hline Major adverse event & 10 & 15.9 & & & 9 & 8.5 & & & 0.14 \\
\hline Early mortality & 3 & 4.8 & & & 3 & 2.8 & & & 0.51 \\
\hline Reintubation & 11 & 17.5 & & & 14 & 13.2 & & & 0.45 \\
\hline Infection & 8 & 12.7 & & & 4 & 3.8 & & & $0.03 *$ \\
\hline Wound infection & 3 & 4.8 & & & 1 & 0.9 & & & 0.11 \\
\hline Restrictive physiology & 16 & 25.4 & & & 15 & 14.2 & & & 0.07 \\
\hline Arrhythmia & 16 & 9.4 & & & 15 & 8.8 & & & 0.87 \\
\hline Delayed sternal closure & 7 & 11.1 & & & 1 & 0.9 & & & $0.003^{*}$ \\
\hline $\begin{array}{l}\text { Ventilation time }(\mathrm{h}) \\
\quad \text { Prolonged ventilation time }(>24 \mathrm{~h})\end{array}$ & 24 & 38.1 & 18 & $12-48$ & 17 & 16.0 & 16 & $8-24$ & $\begin{array}{c}0.01^{*} \\
0.001^{*}\end{array}$ \\
\hline $\begin{array}{l}\text { ICU LOS (day) } \\
\text { Prolonged ICU LOS (>3 days) }\end{array}$ & 36 & 57.1 & 4 & $2-6$ & 44 & 41.5 & 3 & $2-5$ & $\begin{array}{c}0.07 \\
0.05^{*}\end{array}$ \\
\hline $\begin{array}{l}\text { Hospital LOS (day) } \\
\text { Prolonged Hospital LOS (>7 days) }\end{array}$ & 43 & 68.3 & 9 & $7-17$ & 62 & 58.5 & 8 & $7-12$ & $\begin{array}{l}0.11 \\
0.21\end{array}$ \\
\hline
\end{tabular}

Min: Minimum; Max: Maximum; ICU: Intensive care unit; LOS: Length of hospital stay; * Statistically significant parameter. 
closure, prolonged ventilation times, and prolonged ICU times were observed more frequently in patients under one year of age, and the difference between the groups was statistically significant. There was no significant difference between the groups in terms of LOHS, mortality, and MAE (Table 8).

\section{DISCUSSION}

Although surgical treatment of TOF is currently performed with low mortality, postoperative MAEs, prolonged LOHS, and associated cost increase are still important issues. ${ }^{[1,2,12]}$ A prolonged hospital stay not only increases the cost, but also relates to an adverse long-term neurodevelopmental status. ${ }^{[4,5]}$ Therefore, in our study, we evaluated the LOHS and the factors affecting it. Our secondary aim was to assess possible variables which increased the incidence of MAEs, as well as mortality and morbidity rates in developing countries such as in Turkey. In our study, we observed that high preoperative hematocrit levels were related to prolonged LOHS. The use of TAP, younger age, and Down syndrome prolonged the length of ICU stay. In addition, low preoperative $\mathrm{O}_{2}$ saturation levels and TAP prolonged the duration of MV.

In the literature, the LOHS after TOF surgical repair has been reported as six to eight days..$^{[2,3,9-11]}$ In our study, the mean LOHS was found to be eight (range, 1.0 to 40.0 ) days. In a prospective study of 151 patients evaluating the factors affecting hospital stay after TOF surgical treatment, birth weight, absence or atresia of the pulmonary valve, presence of MAPCA, institution of CPB more than once, duration of arterial cross-clamp (ACC), use of circulatory arrest, neonatal repair, and the lowest hematocrit during CPB were shown to be predictors of hospital stay. Pulmonary annulus Z-score and operation age did not affect the hospital stay. ${ }^{[3]}$ In another study, comorbid factors such as preoperative renal failure, preoperative neurological deficits, and preoperative MV dependence prolonged LOHS. ${ }^{[12]}$ Kirsch et al. ${ }^{[13]}$ also reported that the development of low weight, chromosomal abnormalities, and complications were associated with prolonged LOHS.

In our study, we observed that elevated preoperative hematocrit levels prolonged the LOHS. In recent years, the refugee population in Turkey has been increasing rapidly. Late diagnosis is frequently encountered in this patient population. Thirty-nine $(22.9 \%)$ of our patients were refugees. The mean age of these patients was higher (12 vs. 21.2 months $\mathrm{p}=0.04)$ and mean hematocrit level of these patients was higher (42.7 vs. $48.6 \%$, respectively; $p=0.05$ ). High hematocrit levels may occur as a result of prolonged exposure to the disease. This prolonged exposure may have a negative effect on the preoperative hemodynamic condition.

In the present study, $106(62.3 \%)$ of the patients were over one year old. Although the results were improved in this patient group, there was no statistically significant difference between the groups in terms of mortality, MAEs, and LOHS. Infection development, delayed sternal closure, prolonged ventilation times, and prolonged ICU times were observed more frequently in patients under one year of age, and the difference between the groups was statistically significant. Liu et al. ${ }^{[12]}$ also found that prolonged LOHS was associated with age younger than one year.

Egbe et al. ${ }^{[9]}$ showed that age and weight at operation were related to prolonged ICU stay. Another study by van Dongen et al. ${ }^{[10]}$ in patients under 18 months of age undergoing TOF surgical repair showed that ICU and MV durations were prolonged in patients less than three months of age. In another study examining the factors causing prolonged MV duration, factors such as age, left ventricular end-diastolic volume index, McGoon ratio, Nakata index, previous palliation history, CPB duration, and ventilator-associated pneumonia were associated with prolonged MV durations. ${ }^{[14]}$ In our study, age, low RPA Z-score, Down syndrome, use of TAP, and residual VSD were found to be associated with prolonged MV duration $(\mathrm{p}=0.03, \mathrm{p}=0.05, \mathrm{p}=0.002, \mathrm{p}=0.04$, and $\mathrm{p}=0.03$, respectively). Also, the use of TAP and low preoperative $\mathrm{SaO}_{2}$ were associated with prolonged ICU stay ( $p=0.02$ and $p=0.005$, respectively). In their study, Liu et al. ${ }^{[12]}$ found that Down syndrome was associated with prolonged LOHS, consistent with our findings.

In our study, we observed that the development of MAEs and non-MAE complications prolonged hospital stay, as expected. Infection development, restrictive physiology, reintubation, arrhythmia, and delayed sternal closure were more common in the patients with a longer hospital stay. However, there was no statistically significant difference between the groups in terms of mortality. In addition, the mortality rate was $3.5 \%$, permanent complete $\mathrm{AV}$ block was $2.9 \%$, renal dysfunction was $0.6 \%$, neurological deficit was $1.8 \%$, sudden circulatory arrest was $1.2 \%$, ECMO requirement was $4.1 \%$, reoperation was $2.4 \%$, and MAE incidence was $10 \%$. In the literature, mortality after TOF surgical repair was reported as 0 to $7.5 \% .^{[15-17]}$ Of note, our study was conducted in a developing country and the median age is 12 months. This average age is higher than in developed countries. ${ }^{[7,8]}$ In our 
study, we observed that residual VSD increased the incidence of MAE, even if it was not hemodynamically significant. In a multi-center study by Sandoval et al. ${ }^{[2]}$ involving 2,164 patients who underwent TOF surgical repair in developing countries with the participation of 32 centers, weight and body mass index below the fifth percentile and preoperative $\mathrm{SaO}_{2}$ below $90 \%$ were associated with mortality. We observed that residual VSD (odds ratio: 54.6; 95\% CI: 1.6-1,874.2; $\mathrm{p}=0.03$ ) and pulmonary annulus Z-score (odds ratio: $0.5 ; 95 \%$ CI: $0.3-0.9 ; \mathrm{p}=0.01$ ) were related to mortality. Residual VSD was also a risk factor for MAEs (odds ratio: 12.4; 95\% CI: 1.5-99.9; $\mathrm{p}=0.02$ ).

The main limitations of the present study include its retrospective and single-center design. Given the total number of patients and associated complications, the incidence of MAE might have been affected. Therefore, further multi-center, large-scale studies are needed to establish a conclusion.

In conclusion, preoperative and operative factors such as high preoperative hematocrit, low preoperative oxygen saturation, low pulmonary annulus Z-score, Down syndrome, residual ventricular septal defects, and the use transannular patch are associated with prolonged length of hospital stay, prolonged mechanical ventilation, prolonged intensive care unit stay, and increased development of major adverse events. We believe that preoperative hematocrit levels affecting the length of hospital stay may be related to the long-term exposure to the disease. In particular, in developing countries, the difficulty in reaching health care services and late diagnosis may cause this situation. In addition, transannular patch should be avoided as much as possible and a more aggressive approach for residual ventricular septal defect repair is needed.

\section{Declaration of conflicting interests}

The authors declared no conflicts of interest with respect to the authorship and/or publication of this article.

\section{Funding}

The authors received no financial support for the research and/or authorship of this article.

\section{REFERENCES}

1. Jacobs ML, O'Brien SM, Jacobs JP, Mavroudis C, LacourGayet F, Pasquali SK, et al. An empirically based tool for analyzing morbidity associated with operations for congenital heart disease. J Thorac Cardiovasc Surg 2013;145:1046-57.

2. Sandoval N, Carreño M, Novick WM, Agarwal R, Ahmed I, Balachandran R, et al. Tetralogy of Fallot Repair in Developing Countries: International Quality Improvement Collaborative. Ann Thorac Surg 2018;106:1446-51.
3. Mercer-Rosa L, Elci OU, DeCost G, Woyciechowski S, Edman SM, Ravishankar C, et al. Predictors of Length of Hospital Stay After Complete Repair for Tetralogy of Fallot: A Prospective Cohort Study. J Am Heart Assoc 2018;7. pii: e008719.

4. Newburger JW, Wypij D, Bellinger DC, du Plessis AJ, Kuban $\mathrm{KC}$, Rappaport LA, et al. Length of stay after infant heart surgery is related to cognitive outcome at age 8 years. $\mathrm{J}$ Pediatr 2003;143:67-73.

5. Limperopoulos C, Majnemer A, Shevell MI, Rohlicek C, Rosenblatt B, Tchervenkov C, et al. Predictors of developmental disabilities after open heart surgery in young children with congenital heart defects. J Pediatr 2002;141:51-8.

6. Peterson ED, Coombs LP, Ferguson TB, Shroyer AL, DeLong ER, Grover FL, et al. Hospital variability in length of stay after coronary artery bypass surgery: results from the Society of Thoracic Surgeon's National Cardiac Database. Ann Thorac Surg 2002;74:464-73.

7. Fry DE, Pine M, Jones BL, Meimban RJ. Adverse outcomes in surgery: redefinition of postoperative complications. Am J Surg 2009;197:479-84.

8. Mercer-Rosa L, Pinto N, Yang W, Tanel R, Goldmuntz E. 22q11.2 Deletion syndrome is associated with perioperative outcome in tetralogy of Fallot. J Thorac Cardiovasc Surg 2013;146:868-73.

9. Egbe AC, Mittnacht AJ, Nguyen K, Joashi U. Risk factors for morbidity in infants undergoing tetralogy of fallot repair. Ann Pediatr Cardiol 2014;7:13-8.

10. van Dongen EI, Glansdorp AG, Mildner RJ, McCrindle BW, Sakopoulos AG, VanArsdell G, et al. The influence of perioperative factors on outcomes in children aged less than 18 months after repair of tetralogy of Fallot. J Thorac Cardiovasc Surg 2003;126:703-10.

11. Pasquali SK, He X, Jacobs ML, Shah SS, Peterson ED, Gaies MG, et al. Excess costs associated with complications and prolonged length of stay after congenital heart surgery. Ann Thorac Surg 2014;98:1660-6.

12. Liu M, Druschel CM, Hannan EL. Risk-adjusted prolonged length of stay as an alternative outcome measure for pediatric congenital cardiac surgery. Ann Thorac Surg 2014;97:2154-9.

13. Kirsch RE, Glatz AC, Gaynor JW, Nicolson SC, Spray TL, Wernovsky G, et al. Results of elective repair at 6 months or younger in 277 patients with tetralogy of Fallot: a 14-year experience at a single center. J Thorac Cardiovasc Surg 2014;147:713-7.

14. Li S, Zhang Y, Li S, Wang X, Zhang R, Lu Z, et al. Risk Factors Associated with Prolonged Mechanical Ventilation after Corrective Surgery for Tetralogy of Fallot. Congenit Heart Dis 2015;10:254-62.

15. Tamesberger MI, Lechner E, Mair R, Hofer A, Sames-Dolzer E, Tulzer G. Early primary repair of tetralogy of fallot in neonates and infants less than four months of age. Ann Thorac Surg 2008;86:1928-35.

16. Van Arsdell GS, Maharaj GS, Tom J, Rao VK, Coles JG, Freedom RM, et al. What is the optimal age for repair of tetralogy of Fallot? Circulation 2000;102:III123-9. 
17. Gilboa SM, Salemi JL, Nembhard WN, Fixler DE, Correa A. Mortality resulting from congenital heart disease among children and adults in the United States, 1999 to 2006. Circulation 2010;122:2254-63.
18. Al Habib HF, Jacobs JP, Mavroudis C, Tchervenkov CI, O'Brien SM, Mohammadi S, et al. Contemporary patterns of management of tetralogy of Fallot: data from the Society of Thoracic Surgeons Database. Ann Thorac Surg 2010;90:813-9. 